is perhaps scarcely surprising that there grew up around him a school largely devoted to enzyme chemistry in many varied aspects-the machinery of the cell. The extent to which Sir Frederick's view of the scope of biochemistry is now accepted is the measure of his work, but it is only those who have been privileged to study under his influence in the years during which he has directed his school who can appreciate fully what the subject owes to him. His influence on those who worked with him, even for a short time, was always remarkable. He had the precious gift of illuminating discussions. This was especially evident during 'tea club' meetings of the Department, at which papers were read describing work in progress. Sometimes the audience listened to work which appeared dull and even unimportant, but as soon as the Professor opened the discussion the scene changed, the scattered threads made a pattern and the implication of the work took on a new value. In the experience of his pupils this gift is unique. To be associated with Sir Frederick has resulted for many in a certain libera. tion of the mind which enabled them then and later to approach problems with a new confidence, problems which, but for him, they would have discarded. Many lesser men freeze and inhibit; he thaws and liberates.

\section{The Gas Research Board}

Dr. James GrIEve KING, superintendent of the Fuel Research Station, East Greenwich, has been appointed director of the Gas Research Board. Dr. King, who is fifty-one years of age, is a native of Scotland, where he started his career as assistant to Prof. T. Gray at the Royal Technical College, flasgow, during 1912-1914. During the War of 1914-1918, he was chemist and finally departmental superintendent of Nobel's Explosives Co., Ltd. Dr. King joined the staff of the Fuel Research Station as research chemist in 1919 , becoming chief chemist in 1920 and superintendent in 1941. He has a very wide experience in the field of fuel technology. The long list of his published researches includes a number of papers presented, either alone or in collaboration, at autumn research meetings of the Institution of Gas Engineers. His joint paper with the late Eng.Captain J. F. Shaw, on "Reeent Experiments at the Fuel Research Station upon Production of Solid Smokeless Fuel", was awarded the Institution Gold Medal for 1934, and his joint paper with Mr. James Jamieson, on "Products obtained by the Carboniza. tion of Scottish Cannel in Continuous Vertical Retorts", was awarded the H. E. Jones London Medal of the Institution in 1936. Among his earliest publications was a joint paper, with Prof. T. Gray, on "The Assay of Coal for Carbonization Purposes", which described the now classic Gray-King apparatus.

Dr. Frederick James Dent has been appointed joint assistant director of the Board. Dr. Dent is thirty-seven years of age and is a native of Leeds. $\mathrm{He}$ obtained the B.Sc. degree in gas engineering at the University of Leeds in 1926, the Ph.D. degree in 1929, and was awarded the D.Sc. degree in 1939 . $\mathrm{He}$ won the Arthur Smithells Research Scholarship and the Le Blanc Medal in 1927, and was the Institution Gas Research Fellow for 1927-1929. Since 1929 he has been a research chemist of the Institution of Gas Engineers and more recently of the Gas Research Board, engaged upon investigations for the Joint Research Committee. Dr. Dent has also given special lectures on water gas manufacture in the University of Leeds.

\section{Newton's Library}

Messrs. Henry Sotheran, Litd., of Sackville Street, W.1, are offering for sale the hitherto undispersed portion of Newton's library. The collection includes several books of great personal and historical interest in connexion with their former owner, the most important being copies of the first and second editions of the "Principia" and Isaac Barrow's edition of Euclid. According to the vendor's notice of the sale, the first two contain a number of corrections, cancellations and additions in Newton's handwriting. These copies formed the basis of the new editions and, judging from the fact that the title page of the copy of the first edition was revised, it seems possible that this copy was intended for the printer. The edition of Barrow's "Euclidis Elementa" contains MS. notes in Newton's handwriting, mostly giving the propositions in algebraic notation. Books $\mathrm{V}, \mathrm{VI}$ and $\mathrm{X}$ received his special attention. It seems likely that this copy was actually used by Newton in his undergraduate days at Trinity College, Cambridge, when he had come to appreciate Euclid. Other items of interest include a copy of the second English translation of Euclid-that made by Captain Rudd, engineer-in-chief to the Royalist forces, published in 1651. It may be the copy of which Brewster states that Newton "threw it aside as a 'trifling book'". There are also copies of Barrow's "Lectiones Optica" (1669) and Huygen's "Traité de la Lumière" (1690), each of which contains an inscription by Newton stating that it was a presentation copy from the author. It is well known that Newton corrected the proofs of the former and made several corrections and additions. It is a surprising and unexplained fact that although Newton by this time was almost certainly in possession of his theory of colours, he did not correct Barrow's ideas on the subject.

The books are offered for sale in two lots, one of them consisting of Barrow's "Euclidis Elementa" and the other of 858 items. It is to be hoped that this interesting collection will be disposed of as a whole and that it will remain in Great Britain. It represents all that is left of the 1,896 books which formed Newton's library when he died in 1727 . The complete library was then purchased for $£ 300$ by John Huggins, warden of the Fleet Prison, a near neighbour of Newton's. Huggins' receipt for the $£ 300$ and a complete list of the books is now in the British Museum. He presented them to his son, who pasted his bookplate, bearing the inscription "Revd. Carol. Huggins, Rector of Chinner, in Com. Oxon.", in all his books. They were afterwards sold for $£ 400$ to Dr. James Musgrave, who succeeded Charles Huggins at Chinnor. He pasted his bookplate over that of Charles Huggins, his plate bearing the Musgrave arms and the motto "Philosophemur". The books then disappeared for about 170 years until bundles of them, including one of 200 , were sold at rubbish prices at the sale of Thame Park (belonging to the Musgrave family) in 1920. Barrow's Euclid was one of the items disposed of on this occasion. It is these books which are occasionally found in the secondhand bookshops, though many have gone to the United States and, it is feared, many have been treated as waste paper.

The remainder of the library was discovered in 1928 at Barnsley Park (which also belongs to the Musgrave family) by Col. de Villamil, to whose industry and perseverance we owe the unravelling of the mystery of Newton's library. He also discovered at Somerset House a complete inventory of Newton's 
possessions at the time of his death. This "true and perfect Inventary" is on vellum and is about five inches broad and seventeen feet long. The skins, about thirty inches long, bear, each, a blue sixpenny stamp, and they are all sewn together. From this inventory we learn that Newton "left 362 books in Folio, 477 in Quarto, 1,057 in Octavo, duodecimo and 24 mo., together with above one hundred weight of pamphlets and wast books". The total of volumes was thus 1,896 . These were, we read, in six bookcases and were valued at $£ 270$. The lot of 858 volumes is offered for $£ 5,000$ and the copy of Barrow's Euclid

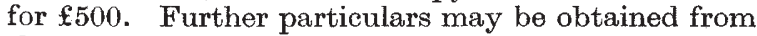
the vendors.

\section{Newton and Alchemy}

NEWTON has been regarded by a number of writers as a credulous alchemist. In some notes on Newton's chemical philosophy written upon the occasion of the tercentenary of his birth, Dr. D. McKie (Phil. Mag., 33,847 ; 1942) disputes this judgment. Newton's interest in chemistry probably began when he was lodging with Clark, the Grantham apothecary, while attending the King's School. He noted down interesting chemical recipes in his earliest note-books when he had a highly practical mind and great skill with his hands. Later on, in 1665 and in 1669, we have records that he bought chemical apparatus and materials. At this time, too, he experimented on the production of alloys that would take a high polish and would therefore be suitable for use as mirrors in the reflecting telescope that he had recently designed. In considering whether Newton should be regarded as a chemist or as an alchemist, Dr. McKie examines Newton's own chemical writings, from which "it would be difficult to conclude that he was 'a credulous alchemist'. Rather, he appears as a pioneer in the study of chemical attraction, as in fact he appeared to many of those who came immediately after him and who held his 'Queries' in such high regard during the eighteenth century". As distinct from his own chemical writings, Newton copied out many long passages and made very extensive extracts from a large number of alchemical writings. Dr. McKie claims that too much significance has been put upon these extracts. Many of them were from rare books, and many alchemical books gave useful information on the properties of the metals and their compounds. Moreover, Newton copied out passages from books that were not alchemical. "We might also ask what man of science would care to be judged by what he had copied out of books." Newton's chemical thought set forth in his published writings shows an advance towards modern chemistry rather than a reversion to the already discredited pursuit of gold-making.

\section{Historical Method in Teaching Science}

Prof. J. Kenner, of the Manchester College of Technology, recently opened a discussion on the "Historical Method in Teaching Science" at a meeting of the Manchester Literary and Philosophical Society. Bearing in mind the need to produce able rather than merely learned men, Prof. Kenner examined the matter, first from the wider point of view of the problem of general education, and quoted from recent articles indicating failures caused by "inadequacy of outlook, a whole method of approach" and by lack of a creative and forward-looking spirit. If those failures are to be avoided in the future, he urged close examination of our educational scheme. If education be defined as deliberate adjustment to environment, he insisted that "if this environment is to be healthy, it must be progressive". Put more fully, his view was that education "should be conceived and designed as a training for life in a progressive environment", and each should contribute to its progress according to his ability. Prof. Kenner recommended that natural science should be taught as a record of progress and of the methods by which that progress has been achieved. Separate courses on the history of science are not necessary. It should be an integral part of teaching. Appreciation of science, its discipline, its procedure and its possibilities are not only useful intrinsically "but also as a criterion of proposed public policy in regard to it". One of the main difficulties in the War, Prof. Kenner pointed out, lies in the present examination requirements.

\section{Reconstruction. Problems in School and Home}

AN interim report has just been issued by the Electrical Association for Women giving the Association's point of view on post-war reconstruction as affecting education and careers, housing and kitchen planning, and electricity in the home, coupled with the design and performance of electrical apparatus and appliances. So far as education and careers are concerned, it is considered that school buildings must be designed for many age-groups, they should show a high æesthetic standard of design, be of high-grade materials, and pay proper attention to health and comfort. The school should be the centre of juvenile life and a meeting-place for parents and teachers. Greater consideration should be given to domestic subjects both for girls and boys, so that domestic science shall take its rightful place, providing training for new careers in the post-war world and a basis for citizenship. As regards housing and kitchen planning, homes should be designed to meet the varying requirements of different types of occupants-. families, single persons, the aged, etc. Public services such as electricity, main water and drainage, and telephones should be universally available.

In the sphere of electrical equipment, it is pointed out that electricity as a source of domestic power is increasingly popular with housewives who want etficiency and economy. Standardization of voltage, current, apparatus, and accessories such as plugs, sockets, switches, connectors is desired. Table-type cookers and refrigerators should generally be installed in order to avoid stooping. Every newly built home should have its built-in refrigerating unit. Good kitchen lighting is imperative. Women want efficiency instead of 'ornamentation'; they are even prepared to forgo variety if good design and performance is within the reach of all. These are the salient features in the report, collated by Elsie E. Edwards, which is the culmination of two years study by women in all parts of Great Britain.

\section{Livestock Management and Public Health}

Ar a meeting of the Backs to the Land Club on March 25, the subject of hygiene in connexion with domestic food production was discussed. Prof. J. W. Munro said that scientific men would be willing to tackle any problems that 'backyarders' might be confronted with in the avoidance of public nuisance. Mr. W. MeA. Gracie, director of Infestation Control at the Ministry of Food, referred to the problem of rats, and it was agreed that by making knowledge 